\title{
BALANCED SCORECARD NA GESTÃO DE COMPRAS: APLICAÇÃO AO CASO DE UNIDADES GESTORAS DO EXÉRCITO BRASILEIRO
}

\section{ARTIGO ORIGINAL}

FARIA, Jonathan Matos de ${ }^{1}$

MARIA, Herventon Francisco de Assis ${ }^{2}$

FARIA, Jonathan Matos de. MARIA, Herventon Francisco de Assis. Balanced Scorecard na gestão de compras: aplicação ao caso de Unidades Gestoras do Exército Brasileiro. Revista Científica Multidisciplinar Núcleo do Conhecimento. Ano 05, Ed. 12, Vol. 10, pp. 106-134. Dezembro de 2020. ISSN: 2448-0959, Link de acesso: https://www.nucleodoconhecimento.com.br/administracao/gestao-decompras

\section{RESUMO}

O objetivo deste estudo é analisar os impactos da metodologia Balanced Scorecard no setor de compras de Unidades Gestoras do Exército Brasileiro, através do modelo de mapeamento e avaliação de desempenho das perspectivas Balanced Scorecard. Para tanto, foram coletados dados em 15 Unidades Gestoras no Rio de Janeiro, em indivíduos direta e indiretamente ligados ao setor de compras. A pesquisa pode-se caracterizar como descritiva e exploratória e os instrumentos utilizados foram, questionário semiestruturado, a observação direta e entrevista. Os resultados do estudo mostraram que, o processo de aquisição de bens e serviços em Unidade

\footnotetext{
1 Pós-graduado em Administração Pública, Gestão e Finanças pela Faculdade IPPEO; Pós-graduado em Logística Empresarial pela Faculdade Signorelli; Graduado em Administração pela UFRRJ.

${ }^{2}$ Orientador. Doutorado em Ciências Militares. Especialização em Política, Estratégia e Alta Administração Militar. Especialização em MBA executivo. Graduação em Ciências Militares.
} 
Gestora é marcado pela necessidade de capacitação dos gestores, de aprimoramento de processos internos e de integração entre setores. Pode-se concluir que embora a cultura do planejamento e integração não esteja plenamente incorporada no setor de compras, existe um cenário oportuno a criação de ações de fácil implantação para o setor, com a elaboração de estratégias, objetivos, metas para a efetividade na gestão.

Palavras-chave: Gestão de compras, Balanced Scorecard, Administração pública.

\section{INTRODUÇÃO}

As organizações públicas, assim como as organizações privadas, objetivam atingir e cumprir os objetivos e metas estabelecidos pela natureza de suas missões institucionais. Para alcançar resultados mais eficientes, tais órgãos públicos buscam realizar aquisições de bens e serviços específicos que se enquadrem em cada perfil de entidade. Sobre tal contexto, este estudo está voltado acerca da gestão de compras das unidades gestoras do Exército Brasileiro, também denominadas de quartéis ou organizações militares.

A temática da Defesa no Brasil abrange temas diversificados desde guerras, segurança de Grandes Eventos, operações de garantia da lei e da ordem (BRASIL, 1988), combate à seca ou doenças (BRASIL, 2012). Desta forma, é exigido das Forças Armadas ações flexíveis e imediatas que por seu turno, carecem de uma base de planejamento e gestão estratégica sobre todos os prognósticos e cenários possíveis. Diante deste quadro, as Forças Armadas necessitam apresentar elevados índices quantitativos e qualitativos na mobilização de recursos através da gestão e do planejamento estratégico. Sobre isto, Petri et al (2014) apontam que principalmente na gestão de recursos públicos, o planejamento estratégico é indispensável no que diz respeito a evitar desperdícios e alcançar a excelência nos serviços. Kaplan e Norton (1997) atestam ainda que no caso de organizações públicas, devem desenvolver objetivos tangíveis e que a medição de desempenho deve ser obtida pelo grau de eficácia e eficiência com que as mesmas atendem as necessidades de seus participantes. Logo, vê-se a necessidade da implementação estratégica de recursos na contribuição e no atendimento eficiente das atividades da Administração Pública. 
Nesse sentido, a aplicação Balanced Scorecard no setor de compras pode proporcionar a execução das atividades das Unidade Gestoras de recursos do EB, de modo a alcançar um desempenho competente. O BSC, segundo Kaplan e Norton (1997), é uma metodologia de gestão de desempenho que apresenta um sistema de medidas que além dos indicadores financeiros de desempenho, utiliza dados com métricas não financeiras para a criação de cenários na organização. Aplicado no gerenciamento de compras organizacional, o mesmo visa proporcionar uma integração das atividades, na medida em que, funciona como uma ferramenta de gestão de desempenho e, principalmente, delimita a estratégia de compras em ações claras e objetivas de performance, proporcionando a compreensão e envolvimento de todas as partes envolvidas.

\section{PROBLEMA}

Quais os impactos da implantação da metodologia Balanced Scorecard na gestão de compras de unidade gestora do Exército Brasileiro?

\section{OBJETIVO GERAL}

Analisar os impactos da metodologia Balanced Scorecard no setor de compras de Unidades Gestoras do Exército Brasileiro no Rio de Janeiro.

\section{OBJETIVOS ESPECÍFICOS}

- Levantamento Bibliográfico da Gestão de compras e Balanced Scorecard;

- Identificação das perspectivas da missão, visão, valores, na gestão de compras em Unidades Gestoras;

- Avalição das forças e fraquezas, oportunidades e ameaças no setor de aquisições, licitações e contratos;

- Análise da metodologia Balanced Scorecard e elaboração de Mapa Estratégico na gestão de compras de unidades gestoras do Exército Brasileiro no Rio de Janeiro. 


\section{FUNDAMENTAÇÃO TEÓRICA}

O sistema de compras é um dos processos fundamentais no que diz respeito ao gerenciamento dos suprimentos de uma organização. Segundo Bowersox e Closs (2004), o principal objetivo do processo de aquisição é a disponibilização, em tempo hábil e no menor custo possível, de todos os insumos necessários às atividades organizacionais. Igualmente, este processo, se mostra como a primeira interface da organização com seus stakeholders. Martins e Alt (2001) estabelecem que tem por atribuição a percepção das demandas dos produtos e serviços e é o setor responsável pela entrega no período correto e no adequado valor dos custos, da qualidade e de quaisquer outras variáveis julgadas estratégicas à organização. Para que este quadro ocorra, o autor aponta sobre a necessidade da imersão e envolvimento dos gerentes de compras nas mais variadas ações que envolvam desde as negociações até a armazenagem de dados e informações.

O principal objeto da gestão de compras é a disponibilização dos insumos necessários às operações em tempo hábil e, principalmente, ao menor custo total (BOWERSOX E CLOSS, 2004). Gaither e Fraizer (2001, p. 16) afirmam que o setor de compras tem por missão "perceber as necessidades competitivas dos produtos e serviços, tornando-se responsável pela entrega no tempo certo, custos, qualidade e outros elementos na estratégia de operações". Ballou (2006) apresenta um conceito mais abrangente, ao afirmar que a função de compras deve ter foco no gerenciamento das relações com os stakeholders estratégicos, ao invés de apenas tratar do processo tradicional da realização de cotações e as consequentes compras. O autor ainda, demonstra que o objetivo da gestão de compras gira em torno do apoio ao processo de gestão da manufatura e da criação de novos bens e serviços, ao passo que, concomitante a isto, deve haver o desenvolvendo de ferramentas de comunicação e armazenamento e análise de banco dados através de mecanismos de tecnologia da informação. Ainda quanto aos objetivos, Martins e Alt (2001, p. 67) comentam que:

Os objetivos de compras devem estar alinhados aos objetivos estratégicos da empresa como um todo, visando o melhor atendimento ao cliente externo e interno. Essa preocupação tem tornado a função 
compras extremamente dinâmica, utilizando-se de tecnologias cada vez mais sofisticadas e atuais como o EDI, a Internet e cartões de crédito.

Diante disto, para Ballou (2006), as ações de compras devem envolver uma série de variáveis como escolha de fornecedores, qualidade de serviços, prazos de entregas, previsão de orçamentos e possíveis demandas, entre outros. Igualmente, o autor comenta a oportunidade das compras para o aumento de rendimento para as organizações. Uma vez que o dinheiro obtido das vendas é utilizado para quitar dívidas de fornecedores, os gestores podem realizar ações com vista a redução de aquisições de insumos que, como resultado, podem gerar maior aproveitamento nos lucros. Acerca das possibilidades que a gestão de aquisições oferece, Dias (2004, p.259) aponta que:

A função compras é um segmento essencial do Departamento de Materiais ou Suprimentos, que tem por finalidade suprir as necessidades de materiais ou serviços, planejá-las quantitativamente e satisfazê-las no momento certo com as quantidades corretas, verificar se recebeu efetivamente o que foi comprado e providenciar armazenamento.

Ballou (2006) reafirma o ser essencial da função compras em uma organização, ao demonstrar que de modo geral os itens adquiridos através das compras representam o porcentual entre $40 \%$ e $60 \%$ do valor de venda do produto final. Isto significa para as empresas privadas que ganhos na gestão de compras, mesmo que rasos, resultam em impacto nos lucros. Quanto às empresas públicas, tal preocupação pode resultar em custos de recursos menores, que por sua vez, podem ser remanejados para custear outras ações governamentais. Porter (1986) confirma este pressuposto, ao defender em seu texto a relevância estratégica das relações entre aqueles que compram e aqueles que fornecem, com intuito da obtenção da vantagem competitiva para as organizações.

A gestão de compras no Exército, além do contexto acima citado, segue os moldes constitucionais preconizados para toda a administração pública brasileira através de licitação e em casos específicos pela dispensa de licitação ou inexigibilidade. Meireles (2010, p. 283) define licitação como: 
[...] o procedimento administrativo mediante o qual a Administração Pública seleciona a proposta mais vantajosa para o contrato de seu interesse, inclusive o da promoção do desenvolvimento econômico sustentável e fortalecimento de cadeias produtivas de bens e serviços domésticos. Como procedimento, desenvolve-se através de uma sucessão ordenada de atos vinculantes para a Administração e para os licitantes, o que propicia igual oportunidade a todos os interessados e atua como fator de eficiência e moralidade nos negócios administrativos.

A licitação, segundo a Lei 8.666/93 (BRASIL, 1993) possui modalidades de licitação: concorrência, tomada de preços, convite, concurso, leilão e pregão (Lei № 10.520/02). Em 2005, conforme Santos (2011) foi regulado o pregão na forma eletrônica através do Decreto no 5.450/05. Esta modalidade segundo o autor é a mais utilizada na Gestão de Compras do Exército.

Acerca dos tipos de licitação, a Lei 8.666/93 (BRASIL, 1993) elenca ainda os seguintes tipos de licitação: menor preço; melhor técnica; técnica e preço; maior lance ou oferta. Igualmente, é obrigatória a previsão, no ato de convocação da licitação, o tipo que será adotado. Da mesma forma, Meirelles (2010) mostra que os casos de utilização de cada modalidade e tipo de licitação irão variar de acordo com a especificidade de cada bem ou serviço desejado pela gestão pública. De certo, todas as modalidades e tipos usados para a gestão de compra pública objetivam a prática ordenada de ato jurídico com o fim de firmar o mais adequado contrato possível, mesclando qualidade, preço e atendimento do interesse público.

A atividade de compras na Administração Pública também é desenvolvida com base nos institutos da descentralização e da desconcentração. Di Pietro (2011, p.420) aborda essas temáticas aduzindo:

Descentralização é a distribuição de competências de uma para outra pessoa, física ou jurídica. Difere da desconcentração pelo fato de ser esta uma distribuição interna de competências, ou seja, uma distribuição de competências dentro da mesma pessoa jurídica [...]

Afirma Meireles (2010, p. 803), ainda, que a desconcentração é a "repartição de funções entre os vários órgãos (despersonalizados) de uma mesma Administração, sem quebra de hierarquia." Nesse sentido, o Comando do Exército desconcentra suas 
atividades de aquisições e contratações, delegando tais atribuições a outras Organizações Militares, classificadas como Unidades Gestoras. Segundo Brasil (1990, p. 2), uma UG é "a Organização Militar estruturada para o exercício de administração própria, possuindo competência para gerir bens da União e de terceiros". Por sua vez, Mota (2009, p. 209) conceitua unidade gestora como:

[...] a unidade investida no poder de gerir créditos orçamentários e recursos financeiros, próprios ou sob descentralização. É a unidade orçamentária ou administrativa. Unidade gestora é um conceito utilizado no Siafi para representar uma repartição de um órgão da Administração Federal que pode ter funções de unidade orçamentária [...]. Há uma tabela de unidades orçamentárias no Siafi. Cada unidade orçamentária é representada por um código de cinco dígitos (99999). Essa tabela identifica a unidade gestora, que é representada por um código de seis dígitos (999999), sendo encarregada da execução dos créditos aprovados em nome da unidade orçamentária. [...]

A Organização Militar, segundo Santos (2011), é classificada como Unidade Gestora por ato do Comandante do Exército. Essa classificação permite com que recursos orçamentários sejam destinados para gestão autônoma desta OM. Excepcionalmente, a aquisição ou contratação de itens e serviços é centralizada em alguma Organização classificada de provedora, no intuito da economicidade, da aquisição de altas quantidades ou bens e serviços muito específicos.

Por sua vez, o Balanced Scorecard (BSC), Indicadores Balanceados de Desempenho, é uma metodologia de gestão desenvolvida no início da década de 1990 pelos estadunidenses Robert Kaplan e David Norton, da Harvard School of Business, no intuito de criar uma ferramenta de avaliação de desempenho organizacional através da mensuração além dos indicadores financeiros. Os estudos realizados com diversas empresas tinham como motivação encontrar um método de avaliação de desempenho que fosse além dos indicadores financeiros, uma vez que, este fato prejudicava a capacidade das empresas de criar valor para o futuro. Assim, a conclusão das análises mostrou a viabilidade de um novo sistema de gestão que utilizava indicadores financeiros e não financeiros na gestão estratégica das organizações. 
Já em 1992, este novo modelo passou a ser reconhecido como um sistema de medição de desempenho e ferramenta para a estratégia organizacional. (KAPLAN E NORTON, 1997). O termo Balanced Scorecard, conforme Kaplan e Norton (1997) tem origem nas discussões realizadas em meados da década de 1990, no Instituto Nolan Norton e está relacionado com as limitações dos sistemas de avaliação de desempenho da época.

As discussões em grupo levaram a ampliação de scorecard que se transformou no que chamamos de "Balanced Scorecard", organizado em torno de quatro perspectivas distintas (...). O nome refletia o equilíbrio entre objetivos de curto e longo prazo, entre as medidas financeiras e não financeiras, entre indicadores de tendências (leading) e ocorrências (lagging) entre as perspectivas internas e externas de desempenho. (KAPLAN e NORTON, 1997, p. 8)

Crepaldi (2004, p. 302) define o Balanced Scorecard "como um Sistema de Gestão Estratégica que permite a tradução da Visão, Missão e Aspiração Estratégica da empresa em objetivos tangíveis e mensuráveis". Serra; Torres e Torres (2004) já explicam o Balanced Scorecard como uma metodologia de medição de desempenho através de indicadores financeiros e operacionais. O BSC mede resultados e aplica direcionadores da organização em entendimento com suas estratégias (MOTTA, 2003). Igualmente, Vieira e Petri (2014) colaboram ao afirmarem que o BSC é uma ferramenta de assimilação, por parte da organização e de seus integrantes, do planejamento estratégico e das ações pretendidas, ou seja, o desempenho organizacional. Quanto a isto, os criadores do BSC, Kaplan e Norton (1997, p. 320) ressaltam ainda que "como cada estratégia é única, cada scorecard deve ser único e conter vários indicadores únicos".

"As empresas não conseguem mais obter vantagens competitivas sustentáveis com a rápida alocação de novas tecnologias a ativos físicos, e com a excelência da gestão eficaz dos ativos e passivos financeiros". (KAPLAN; NORTON, 1997, p. 3). As organizações necessitam de um sistema para implementação de estratégia e compreensão da mesma por parte dos seus membros da organização, de forma que os recursos sejam aplicados conforme os objetivos traçados no planejamento 
(KAPLAN; NORTON, 1997). Para os autores o BSC pode possibilitar esse contexto estratégico.

O Balanced Scorecard traduz a missão e a estratégia em objetivos e medidas, organizados segundo quatro perspectivas diferentes: financeira, do cliente, dos processos internos e do aprendizado e crescimento. $\mathrm{O}$ 'scorecard' cria uma estrutura, uma linguagem, para comunicar a missão e a estratégia, e utiliza indicadores para informar os funcionários sobre os vetores do sucesso atual e futuro. Ao articularem os resultados desejados pela empresa com os vetores desses resultados, os executivos esperam canalizar as energias, as habilidades e os conhecimentos específicos das pessoas na empresa inteira, para alcançar as metas de longo prazo. (KAPLAN E NORTON, 1997, p. 25)

Segundo Kaplan e Norton (1997, p. 11) "não se pode melhorar o que não se pode medir". Nesse sentido, a gestão organizacional eficiente carece de um sistema de melhoria contínua. Logo, o gestor deve implantar um sistema de medição de desempenho, no intuito de adquirir informações gerenciais que de todos os resultados. Dalfovo e Lima (2009) citam que as informações representam para as organizações poder, na medida em que, a informação proporciona aos gestores decisões fundamentadas. Deste modo, a ferramenta utilizada pelo Balanced Scorecard para tal acompanhamento na gestão é utilização de indicadores de desempenho. Kaplan e Norton (2001) demonstram que um sistema sobre gestão de indicadores procura quantificar e qualificar os resultados, na medida em que, sua finalidade é analisar eventos, cenários, limitações e a tomada de decisões. Por conseguinte, um sistema de indicadores proporciona um grau maior de compromisso com resultados, mediante a determinação de metas de desempenho que expressem os sucessos esperados em termos de quantidade e qualidade dos serviços prestados e da efetividade e eficiência com que são oferecidos.

Independente de organismo público ou privado, segundo Kaplan e Norton (1997), os indicadores de desempenho do BSC são utilizados sem restrições. Os mesmos são divididos em quatro perspectivas: financeira, clientes, processos internos, e aprendizado e crescimento. Segundo Kaplan e Norton (1997, p.44):

A vinculação entre as medidas das quatro perspectivas mostra claramente que os scorecard não é um agregado de aleatórios de duas 
dúzias de medidas que executivos misturam e escolhem ao acaso. Ao contrário, num bom Balanced Scorecard, as medidas devem ser interligadas para comunicar um pequeno número de temas estratégicos amplos, como o crescimento da empresa, redução dos riscos e aumento de produtividade.

A perspectiva financeira, conforme Kaplan e Norton (1997, p. 50), têm por missão "definir o desempenho financeiro esperado da estratégia e servir de meta principal para os objetivos e medidas de todas as outras perspectivas do Scorecard". A partir disto vê-se que a perspectiva financeira citada pelos autores, diz respeito à consequência do desempenho financeiro, ou seja, métricas de lucratividade e rentabilidade da organização. Estes indicadores, se analisados isoladamente, atestam somente os resultados financeiros obtidos. Todavia, no BSC estes indicadores são complementados com outras perspectivas não financeiras. Como exemplo, podem-se citar os índices de satisfações e percepções dos clientes. Esta aplicação de indicadores possibilita avaliar o desempenho da estratégia perante os resultados financeiros. Ainda conforme Kaplan e Norton (1997), essa perspectiva é dividida em três fases distintas: crescimento (etapa que compreende o objetivo de crescimento de receita e vendas), sustentação (busca da ampliação da lucratividade, investimentos e melhoria contínua das ações) e colheita (etapa de resultados oriundos das ações anteriores)

Tal perspectiva é influente nas organizações privadas e públicas, na medida em que, no privado, o desempenho financeiro indica a atuação da estratégia no lucro e sustentabilidade do negócio. No setor público, esta perspectiva permite analisar a eficiência e redução e custos das ações governamentais (MOTTA, 2003). Costa e Almeida (2005, p. 91) mostram a importância dos indicadores financeiros para as organizações governamentais, na medida em que, dizem que "a empresa pública, que não tem o objetivo de lucro, mantém o foco apenas na viabilização de suas estratégias para o benefício da sociedade".

Motta (2003) e Melgaço (2003) mostram que a perspectiva financeira do BSC, para a gestão pública, não é o propósito final, e sim apenas um meio de captação de recursos para a realização da sua responsabilidade social. Nesse sentido, percebe-se que a 
obtenção e execução orçamentária são variáveis vitais para o cumprimento das funções sociais das organizações públicas. Nesse sentido, Osório (2003) aponta o orçamento como $\mathrm{o}$ agente limitador das ações governamentais. $\mathrm{O}$ autor afirma ainda que a falta de uma execução orçamentária efetiva, ocasiona para os entes públicos dificuldades no cumprimento de suas missões sociais, como também na obtenção de recursos para manutenção, conservação e aquisição de equipamentos e melhorias na infraestrutura e nos recursos humanos. Por tal, na área pública a perspectiva financeira deve ser orientada para o cumprimento efetivo do orçamento e não na busca de lucro. Ainda segundo Osório (2003), o setor público não busca atender o interesse de acionistas, mas sim atender as necessidades sociais. Nesse sentido, na área pública perspectiva financeira/orçamento deve ser tratada como uma perspectiva de base para a formulação dos mapas estratégicos do BSC.

A perspectiva de clientes, por sua vez, é orientada para indicadores voltados para o cliente. Isto diz respeito a medidas quanto a percepções, satisfações, reclamações de clientes, além do reconhecimento da imagem e reputação da organização, em prol do direcionamento das suas ações para a consolidação e gerência de seus clientes e stakeholders. A seleção destas medidas necessita da definição de pontos sobre o público-alvo e o que os mesmos aguardam da organização (SERRA; TORRES; TORRES, 2004). Esta perspectiva tem início na identificação dos clientes e mercados que se almeja atingir. É necessário também a identificação do valor que será oferecido aos mesmos (KAPLAN e NORTON, 1997). Os autores demonstram que as organizações que buscam posição de liderança perante o mercado de consumidores, necessitam orientar seus esforços em favor dos clientes. Quanto a isto, enfatizam Kaplan e Norton (1997, p. 67).

Antes, as empresas podiam se concentrar em suas capacidades internas, enfatizando o desempenho dos produtos e a inovação tecnológica. Porém, as empresas que não compreenderam as necessidades dos clientes acabaram constatando que os concorrentes Ihe tomavam mercado oferecendo produtos ou serviços melhor alinhados às preferências desses clientes. Por isso, as empresas hoje estão voltando seu foco para fora, para os clientes. 
Já a perspectiva de Processos Internos, segundo Kaplan e Norton (1997), se origina devido aos novos processos tecnológicos cada vez mais complexos nos negócios. Os autores mostram que a perspectiva de processos internos é aplicada sobre os indicadores internos da organização. Na visão de Kaplan e Norton (1997, p.121), "na perspectiva dos processos internos, os executivos identificam os processos críticos em que devem buscar a excelência, a fim de atender aos objetivos dos acionistas e de segmentos específicos de clientes". Este método emprega as medidas de produtividade, eficiência, competitividade, entre outras para favorecer a identificação das ações que produzem impacto na satisfação dos clientes e no desempenho financeiro (SERRA; TORRES; TORRES, 2004). A organização identifica os elementos que podem ser aprimorados. Assim, é possível descobrir a carência de novos projetos e ações direcionados para os objetivos organizacionais.

Kaplan e Norton (2000) classificam esta perspectiva em três fases distintas, a saber: processo de inovação (compreende a identificação e dimensionamento do mercado, da preferência dos clientes e o desenvolvimento de ideias de oportunidades do negócio), processo de operações (ações que envolvem a criação e desenvolvimento de produtos e serviços) e processo de serviço pós-venda (acompanhamento de processos de pagamento, correção, garantias e processamento de demandas após a venda).

Finalmente, Kaplan e Norton (1997) mostram a perspectiva de aprendizado e crescimento. Esta última examina as ações referentes aos indivíduos no que tange ao treinamento de práticas e processos, ao clima e cultura organizacional com o fim de caracterizar as circunstâncias que produzem o aperfeiçoamento e desenvolvimento constante. Nesse sentido, esta perspectiva busca a resposta sobre como a organização deve se portar para alcançar um desempenho superior. Kaplan e Norton (2004) mostram que aprendizado e crescimento contempla os indivíduos e a gestão interna como um todo, através do aperfeiçoamento de tecnologia da informação e das práticas gerenciais. Essa perspectiva ainda segundo os autores aponta para três categorias: capacidade dos funcionários, capacidade dos sistemas de informação e motivação, empowerment e alinhamento. 
A capacitação dos profissionais deve ser um dos principais investimentos das organizações. "As ideias que permitem melhorar os processos e o desempenho para o cliente cada vez mais emanam dos funcionários da linha de frente, que se encontram mais próximos dos processos internos e dos clientes da organização". (KAPLAN e NORTON, 1997, p. 133).

De maneira similar, Kaplan e Norton (1997, p. 41) mostram a importância da capacidade dos sistemas de informação ao afirmarem que "serviços de informações excelentes são uma exigência para que os funcionários melhorem os processos, seja continuamente, (...) seja descontinuamente, através do redesenho ou da reengenharia dos processos". Sobre a última categoria, Camelo e Vidal (2006, p. 10), explicam a forma prática da categoria de motivação, empowerment e alinhamento:

Manter um ambiente propício à participação ativa dos funcionários é uma maneira efetiva de se estruturar uma aprendizagem em circuito duplo. Pois, um fator decisivo para a motivação dos funcionários é a oportunidade de participação no processo organizacional, ou seja, perceber que a sua atividade contribui, de alguma forma, para o desenvolvimento da empresa. Para tanto, é necessário que a organização estabeleça programas que favoreça o empowerment, proporcionando uma relação mais direta entre o planejamento e as ações operacionais. Diante dessa perspectiva se faz necessário que se estabeleça um alinhamento entre as ações atuais e as propostas de mudança, tanto em nível individual como em nível departamental, com os objetivos a serem alcançados pela organização.

O Balanced Scorecard, expressa como dito anteriormente, o equilíbrio entre objetivos relacionados a proventos quantificáveis e a resultados subjetivos, ambos que influenciam o desempenho organizacional. Isto quer dizer que, o Balanced Scorecard reflete igualdade entre elementos de curto e de longo prazo, entre objetivos financeiros e não financeiros, entre métricas de resultados concretos e cenários de desempenho interno e externo. (KAPLAN E NORTON, 1997). Neste intuito, os autores formaram uma ferramenta lógica e abrangente para a implementação dos objetivos do BSC. Esta ferramenta é apresentada pelos autores como "Mapas estratégicos".

Podem-se delimitar os mapas estratégicos, conforme Kaplan e Norton (2001), como a ferramenta que demonstra a estratégia a ser implementada, ao apresentar as 
relações entre os stakeholders e os processos e capacidade organizacional, e descreve os objetivos para a criação de valor. "Estratégia é um conjunto de hipóteses sobre causas e efeitos". (KAPLAN E NORTON, 1997, p. 30). Segundo Kaplan e Norton (2000, p. 81), o mapa estratégico do BSC explica "a hipótese da estratégia. Cada indicador do BSC se converte em parte integrante de uma cadeia lógica de causa e efeito que conecta os resultados almejados da estratégia com os vetores que induzirão a essas consequências." Essas relações de causa e efeito explicam, no mapa estratégico, as relações entre os objetivos das quatro perspectivas do BSC. Nesse sentido, se figuram como uma ferramenta que explica a estratégia e ações dentro da organização, detalhando ainda a forma com que cada objetivo pode corroborar no desenvolvimento dos objetivos restantes. Tais mapas estratégicos atuam basicamente na medição de indicadores e das perspectivas dos ativos organizacionais e em como estes ativos intangíveis podem gerar resultados tangíveis (KAPLAN e NORTON, 2001).

Kaplan e Norton (1997, p. 322) afirmam, "para que o BSC crie valor, ele precisa ser integrado ao sistema gerencial. Com o tempo, os sistemas de informações gerenciais serão ajustados ao processo". Em síntese, o BSC é uma metodologia que representa a visão da organização. Os objetivos e medidas aplicados sobre os primórdios do BSC, esclarece e comunica tal visão de forma focalizada para a organização. O Balanced Scorecard é mais do que um sistema de indicadores, na medida em deixa a figura de um sistema de medidas e age em um sistema de gestão estratégica que pode ser adaptado tanto na administração privada quanto pública.

\section{CORPO DO TRABALHO/DESENVOLVIMENTO}

A Unidade Gestora no Exército tem uma estrutura administrativa organizada através de níveis hierárquicos, divididos em Comando, Subcomando e o Estado-Maior. Este último possui as seguintes subdivisões: 1ㄹ Seção (Setor responsável pelos Recursos Humanos), $2^{\text {a }}$ Seção (Setor de Inteligência), $3^{\text {a }}$ Seção (Setor de Instrução e Operações) e a 4 $4^{a}$ Seção (Setor de responsável pelo patrimônio) e a Fiscalização Administrativa (Responsável pela gerência da UG). O setor de Fiscalização tem por atribuição realizar "assessoramento do Agente Diretor nos assuntos de administração 
patrimonial e do Ordenador de Despesas na administração orçamentaria e, no que couber, nas administrações financeiras e patrimonial. "(BRASIL, 1990). Nesse contexto é inserido o setor de compras, como uma das ramificações da Fiscalização Administrativa.

Diante deste contexto, antes da apresentação específica do perfil organizacional do Setor de Compras, foi observado na pesquisa a estrutura funcional do sistema de compras da UG. Inicialmente, o Ordenador de despesas é a autoridade máxima que realiza a tomada de decisão sobre a aquisição de bens e serviços (SANTOS, 2011). $\mathrm{Na}$ maioria das $\mathrm{OM}$ analisadas o ordenador de despesas é representado pelo Comandante da OM. Em algumas unidades específicas, a função de ordenador é delegada pelo Comandante a algum outro oficial capacitado para isto. Em ambos os casos, segundo Brasil (1990), constitui a autoridade competente para autorizar as despesas pertinentes as atividades administrativas e operacionais, e, portanto, atingir a missão, objetivos e propósitos da administração pública. A fiscalização administrativa, por seu turno, é o setor responsável pelo assessoramento ao ordenador de despesas com o fim de decidir acerca das aquisições na Unidade. Além disso, tem como atribuição gerir e controlar todo o patrimônio existente na organização militar. Ressalta-se, portanto, que o setor de compras constitui uma ramificação desta área funcional.

O Setor de Compras da Unidade Gestora é denominado de Seção de Aquisições, Licitações e Contratos (SALC). Nele são compreendidas as atividades de compras, licitações e contratos da UG, com a finalidade de adquirir, por exemplo, materiais de expediente, gêneros alimentícios e firmar serviços de correios, água e energia elétrica (SANTOS, 2011). O chefe da SALC responde pela administração, coordenação e controle de todas os processos desenvolvidos na gestão de aquisições, tendo ainda como atribuição informar o Ordenador de Despesas e o chefe da Fiscalização sobre a situação orçamentária e dos processos de contratos e licitatórios. No que diz respeito a distribuição funcional do setor, têm-se as subdivisões de aquisições, licitações e contratos, conforme ilustrado pelo organograma abaixo: 
Figura 1 - Hierarquia do Sistema de Compras

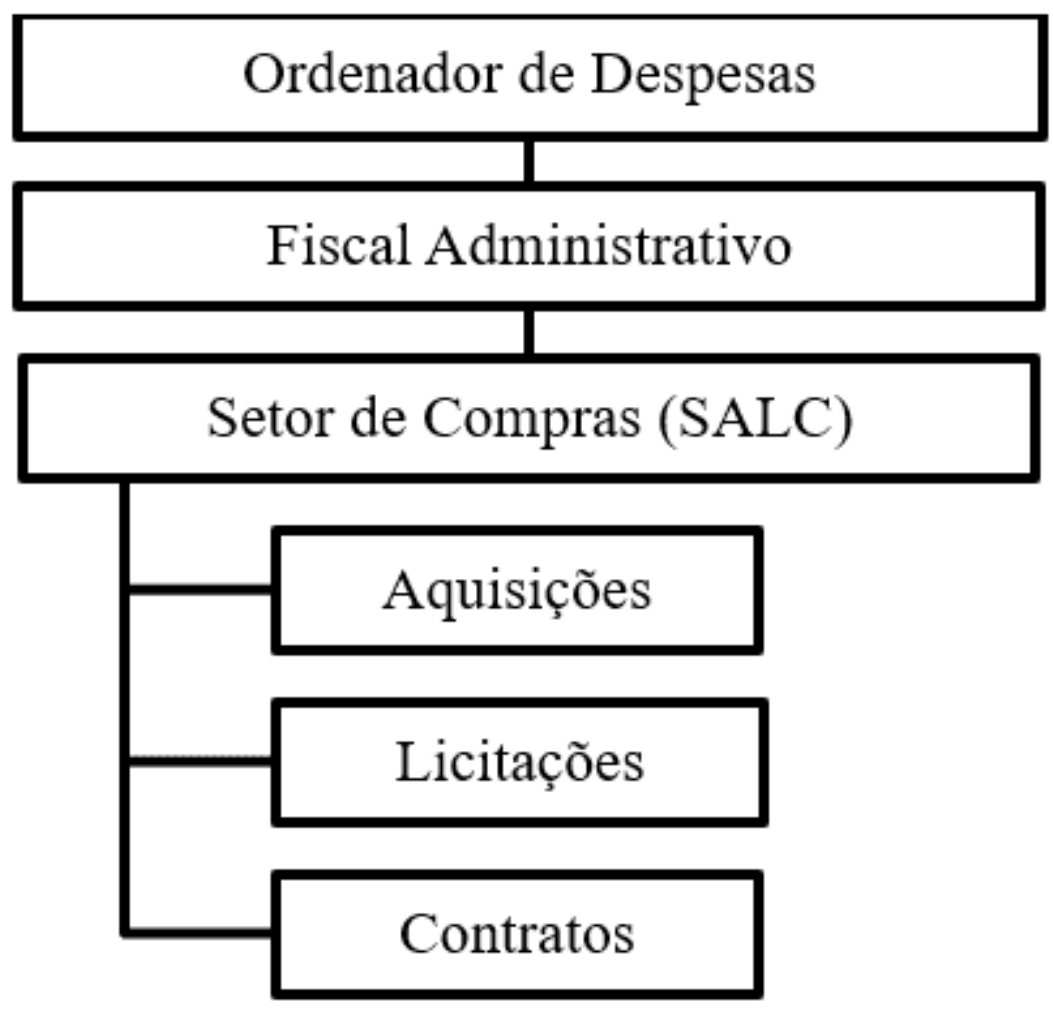

Fonte: Dados da pesquisa, 2020.

\section{ANÁLISE DE SWOT DA SALC}

Esta seção apresenta a percepção dos pontos fortes e fracos e ameaças e oportunidades aos quais a SALC está sujeita. A intenção foi elaborar uma perspectiva ampla acerca do setor, compreendendo as opiniões e percepções dos que trabalham direta e indiretamente sobre a temática de compras nas UG estudadas. No Quadro 2 são apresentadas as respostas mais relevantes dos questionados acerca da análise SWOT.

Quadro 1 - Respostas mais relevantes acerca dos pontos fortes e fracos

Citação direta dos questionados

"Tem um bom ambiente de trabalho (na maioria das vezes), bastante liberdade por parte de seus integrantes para a tomada de decisão e normalmente os 
cargos da SALC são ocupados por militares de confiança. " No que diz respeito aos pontos negativos da SALC: "um melhor planejamento, não só da SALC, mas por parte de toda a administração das OMs, a segregação de função, a falta de alguns recursos e principalmente a falta de conhecimento da função da SALC por aqueles que não são integrantes. "

"Contribuir para as atividades da OM como um todo" como diferencial positivo da SALC. No que tange aos pontos negativos, nessa oportunidade um questionado cita a carência de "formação de equipes capacitadas e motivadas a trabalhar com eficiência e efetividade."

"Autonomia e capacidade de conhecimento para tomar decisões quanto ao emprego dos recursos".

"Foco na legislação mais atualizada e procura do autoaperfeiçoamento constante."

"Transparência e possibilidade de concorrência são, dentre outros, aspectos positivos desse setor."

"Compra com base nos produtos de qualidade e com preço razoáveis de acordo com as regras já ornamentadas".

"Carência de pessoal, no setor, em determinadas OM; Morosidade processual, por parte da assessoria jurídica, nas licitações diversas. "

"Pouco envolvimento do destinatário final do material ou serviço, no processo de aquisição."

"Ter uma relação mais próxima do setor de material, para que os interesses sejam dialogados".

"Falta de experiência e conhecimento dos profissionais que lá trabalham".

"Necessidade de aumentar a equipe para não sobrecarregar o profissional e atender as demandas da seção."

"Alta rotatividade de militares no setor de compras".

Fonte: Dados da pesquisa, 2020. 
No que diz respeito ao ambiente externo e as respectivas oportunidades e ameaças, segue a seguir o próximo quadro formulado a partir da análise de conteúdo das respostas coletadas:

Quadro 2 - Respostas mais relevantes acerca das oportunidades e ameaças

\section{Citação direta dos questionados}

"O EB possui credibilidade exemplar perante a nação segundo pesquisas recentes da mídia brasileira, quanto a isto a área de vendas também se enquadra e deve aproveitar esse contexto para adquirir com mais excelência e capacidade suas compras públicas".

"Deve ser aproveitado, como já é, contudo não em plenitude, a aliança do EB com entidades de ensino de administração pública como a ESAF e ENAP, com intuito de proporcionar melhorias na capacidade dos militares que tratam de compras públicas. Como ameaça existe a dificuldade que é realizar uma licitação, o pouco número de empresas com disponibilidade de material, a nacionalização das compras, ficando difícil receber materiais de outros estados, etc."

Temos como ameaça o pouco tempo de emprego de créditos, pregões indisponíveis devido problemas das empresas ou mesmos dos servidores que formularam o processo licitatório e as limitações e indisponibilidades dos sistemas integrados do Governo Federal para consultar e realizar compras "Os preços de aquisição em um sistema como este são mais elevados devido ao processo utilizado, embora seja o mais indicado não permite barganha num jogo de empresas onde o resultado deve ser bom para ambos e assim encontrar um equilíbrio (...)".

"Compra de produtos alimentícios e logísticos inferiores, ao requisitado devido dos critérios de menor preço das licitações."

"Como ameaças no ambiente externo, temos o pouco tempo hábil dado pelos escalões superiores para emprego de recursos. Além disso, a corrupção de fornecedores oferece um grau substancial nas aquisições, pois, processos licitatórios aos quais referidas empresas são vencedoras, ficam indisponíveis 


\section{para utilização, muitas vezes devido a punições de idoneidade impostas e os preços impraticáveis dos bens e serviços}

Fonte: Dados da pesquisa, 2020.

Além de captar as percepções dos militares acerca das oportunidade e ameaças em que a SALC está sujeita, foi proposto executarem uma classificação acerca do grau que essas variáveis sujeitam o ambiente externo de compras na UG. Conforme Echeveste (2005), essa medição serve de instrumento de avaliação do grau de importância em termos comparativos, ao qual os questionados enumeram os itens mais relevantes. Sobre esse assunto, "as perguntas são transformadas operacionalmente em variáveis e indicadores, apresentadas ao respondente em forma de itens. (...) as respostas representam o grau de conceituação que o respondente tem acerca do assunto sob investigação." (GÜNTHER, 2003, p 9).

Figura 2 - Grau de oportunidades em que a SALC está sujeita

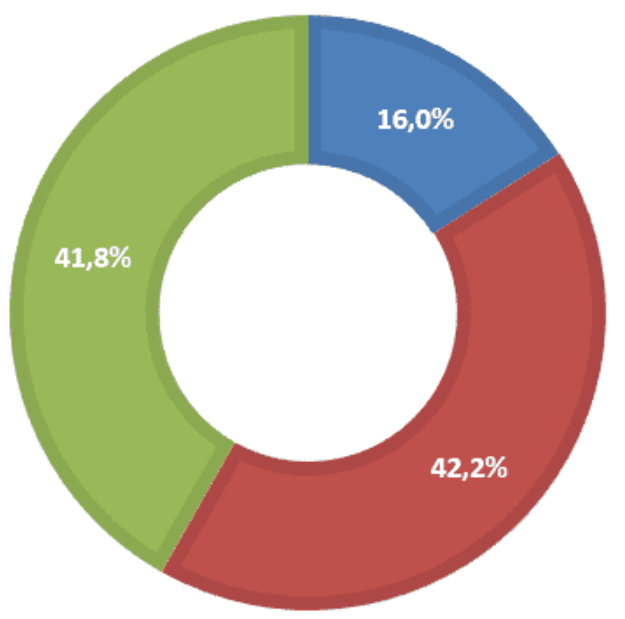

Alto grau de oportunidade (Novas tendências tecnológicas e métodos licitatórios de compras públicas).

- Médio grau de oportunidade (Novas tendências tecnológicas e métodos licitatórios de compras públicas).

- Baixo grau de oportunidade (Novas tendências tecnológicas e métodos licitatórios de compras públicas).

Fonte: Dados da pesquisa, 2020. 
$\mathrm{Na}$ figura 2, vê-se como resultados que a maioria dos respondentes acredita que a SALC esteja inserida em um grau baixo ou mediano de oportunidades. Essa percepção é respondida segundo Meirelles (2010), na medida em que, a SALC como ente da administração, é marcado por um alto grau de burocratização, legislações e regimentos específicos para cada atividade. Esse contexto dificulta a inserção de mudanças radicais de cenários, ambientes e processos.

A figura 3 representa a percepção dos indivíduos envolvidos no processo de compras sobre o grau de ameaças ao qual a SALC está sujeita. Diferente da percepção de oportunidade, a visão dos respondentes quanto a ameaça é de quase $87 \%$ acreditando que estão inseridos num grau mediano ou alto. A partir da análise de conteúdo feita sobre as respostas, percebeu-se que esta noção é devida a dois pontos relevantes: pouco período de tempo hábil de emprego de recursos orçamentários para a compra de bens e serviços e; a corrupção nas licitações que como resultado dificulta o processo de aquisição, na medida em que, conforme Santos (2011), uma UG só pode realizar aquisições através de processos licitatórios, sendo o destaque o pregão eletrônico.

Figura 3 - Grau de ameaças em que a SALC está sujeita

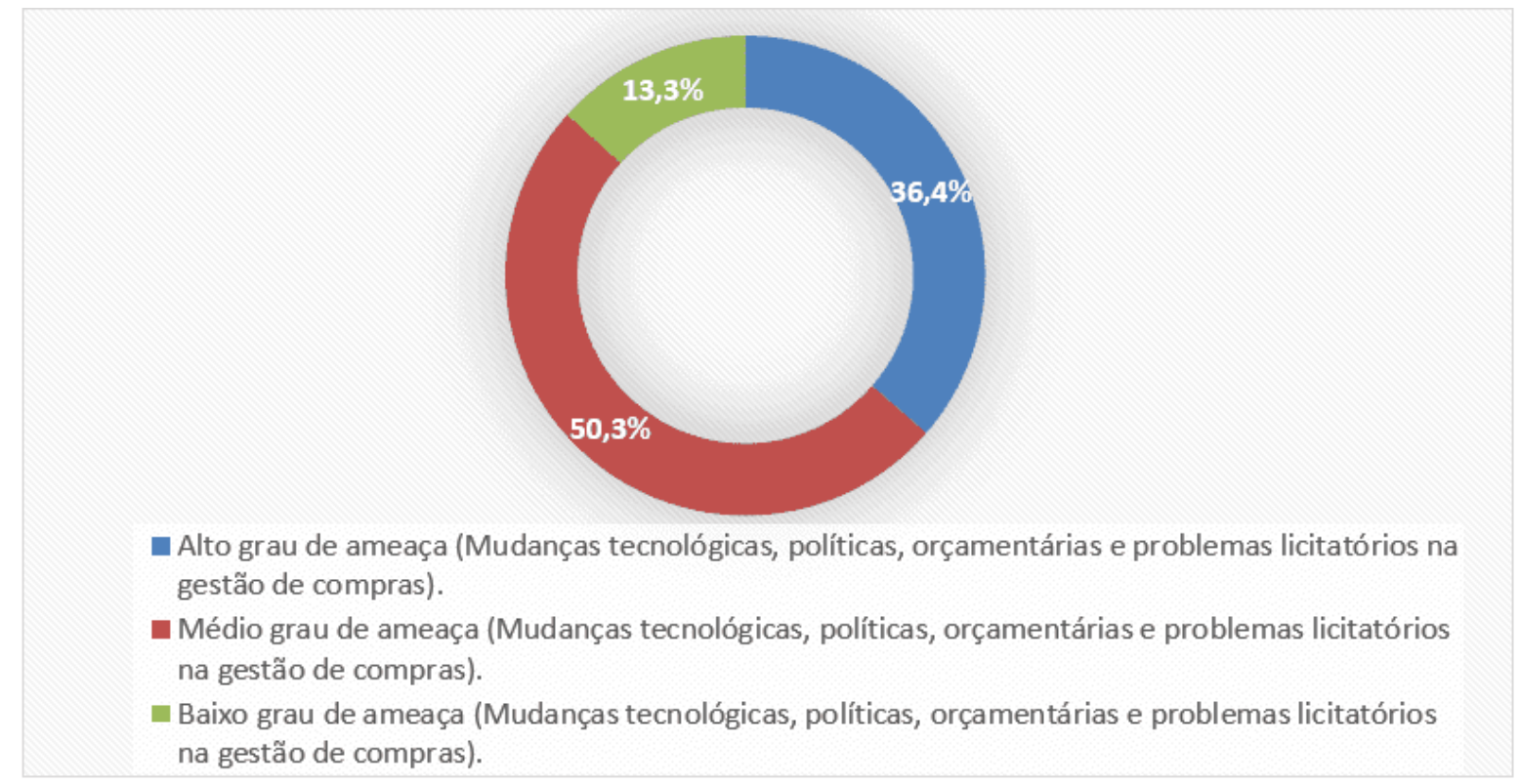

Fonte: Dados da pesquisa, 2020. 
Por derradeiro, o próximo quadro, mostra os resultados das análises de conteúdo realizadas, com a determinação dos principais fatores do ambiente interno e externo que afetam o Setor de Aquisições, Licitações e Contratos de unidades Gestoras.

Quadro 3 - Análise SWOT do Setor de Compras

\begin{tabular}{|c|c|c|}
\hline Ambiente & FORÇAS & FRAQUEZAS \\
\hline Interno & $\begin{array}{l}\text { Atendimento das demandas de } \\
\text { materiais e serviços da OM com } \\
\text { autonomia, transparência e } \\
\text { legalidade; } \\
\text { Ambiente de trabalho agradável e } \\
\text { pautado na confiança; } \\
\text { Cultura de autoaperfeiçoamento; } \\
\text { Sistemas e softwares de } \\
\text { comunicação e trabalho eficazes. }\end{array}$ & $\begin{array}{l}\text { Falta de pessoal especializado } \\
\text { devido a rotatividade dos } \\
\text { integrantes da SALC; } \\
\text { Baixa integração, motivação e } \\
\text { capacitação dos militares que } \\
\text { trabalham indiretamente com o } \\
\text { setor de compras; } \\
\text { Carência de planejamento } \\
\text { estratégico integrado entre os } \\
\text { setores solicitantes e a SALC. }\end{array}$ \\
\hline Ambiente & OPORTUNIDADES & AMEAÇAS \\
\hline Externo & $\begin{array}{l}\text { Reconhecimento de credibilidade } \\
\text { das Forças Armadas no âmbito das } \\
\text { compras públicas, em específico, o } \\
\text { Exército Brasileiro; } \\
\text { Parcerias com organizações } \\
\text { públicas e privadas para a realização } \\
\text { de cursos e especializações sobre } \\
\text { gestão de compras. }\end{array}$ & $\begin{array}{l}\text { Contingenciamento de recursos } \\
\text { orçamentários; } \\
\text { Possibilidade de cortes de } \\
\text { efetivo temporário e } \\
\text { transferências do efetivo de } \\
\text { carreira que integram a SALC; } \\
\text { Problemas de fraudes licitatórias } \\
\text { por parte dos fornecedores que } \\
\text { prejudica a realização de } \\
\text { aquisições. }\end{array}$ \\
\hline
\end{tabular}


Fonte: Dados da pesquisa, 2020.

\section{APLICAÇÃO DO BSC - OBJETIVOS DA PERSPECTIVA FINANCEIRA}

Os objetivos da perspectiva financeira adaptada ao setor público, estão voltados ao orçamento anual que cada UG recebe descentralizado do Comando do Exército. Nesse sentido, o Setor de Aquisições, Licitações e Contratos tem a sua disposição anual recursos para sanar as demandas referentes às atividades administrativas e militares. Exemplos desse custeio estão as despesas com gêneros alimentícios, combustíveis, concessionárias de energia elétrica, água e telefonia, serviços de manutenção e construção, materiais de consumo e de uso duradouro entre outros (SANTOS, 2011). Quanto a este quadro, destaca-se os principais relatos levantados no questionário:

Quadro 4 - Respostas mais relevantes acerca da perspectiva financeira

Citação direta dos questionados

"Há muito desperdício, excesso de compras, tanto no setor alimentício quanto no da limpeza".

"Dentro das possibilidades da administração pública prezam pela lisura e pela eficiência quando recolhido ele é repassado a outra OM".

"Na maioria das vezes não, pois muitas das vezes não temos tempo hábil para fazer a busca de melhores preços e fornecedores."

“(...) $\mathrm{O}$ trabalho, na maioria dos casos, não é feito com previsão; além disso, o período de descontingenciamento constitui um risco ao administrador, pois os prazos para aplicação dos recursos são exíguos e, como não há previsão, os recursos são mal empregados."

“(...) Os recursos poderia ser melhor administrado se houvesse um envolvimento maior do interessado."

"Quando há um planejamento, com pregões vigentes ou "caronas" corretas, os recursos são bem empregados." 
“(...) Os recursos são bem administrados. Esta afirmação tem por base dados do SIAFI que mostram que as FA (EB inserido nesse contexto) possuem o maior grau de empenho de recursos orçamentários no âmbito de todos os ministérios (...)."

"O EB consegue cumprir suas missões mesmo com as deficiências no orçamento, fato prático este que comprova que diante de dificuldades os recursos disponíveis são na medida do possível bem aproveitados. Temos limitações e gargalos como exemplo, corrupção e problemas de eficiência, contudo, no olhar macro os recursos são sim bem aproveitados. "

Fonte: Dados da pesquisa, 2020.

Através da análise de conteúdo, vê-se que os principais pontos levantados pelos questionados foram: falta de planejamento concreto e definido acerca do materiais e serviços a serem adquiridos; pouco envolvimento e motivação dos setores requisitantes de realizar buscas por fornecedores e especificações, que por seu turno, resulta em desperdício ou compra não adequada do item e; tempo curto para a utilização dos recursos que prejudica a busca do item mais adequado e no menor preço. Diante disto, é indispensável que o setor de gestão de compras busque otimizar os custos e despesas anuais, com a finalidade de realizar uma gestão efetiva dos recursos.

Igualmente, foi observado propostas dos respondentes acerca de aumento de receita orçamentária. Conforme observado por um dos questionados “(...) além de buscar a eficiência constante na utilização dos recursos, uma vez que, os prazos de aplicação dos recursos são imediatos, deve-se buscar o aumento de receitas através de cessionários." Dessa forma, a SALC deve buscar através de procedimentos licitatórios legais e específicos a cada UG, angariar fontes de recursos através de cessionários de uso para a UG. A cessão de uso, conforme Meirelles (2010), é a transferência da posse de um bem ou espaço público, a fim de que o cessionário utilize para realizar alguma atividade e em troca o mesmo paga para ter esse direito. Exemplos de cessão de uso para um UG são os serviços de banco, cantina, alfaiataria, barbearia, entre outros. Ou seja, os cessionários exercem os serviços laborais em 
torno ou no interior da OM e em troca pagam através da Guia de Recolhimento da União a taxa de aluguel ou arrendamento por esse serviço (BRASIL, 2017), que por seu turno, resulta no aumento de receita orçamentária para a UG.

\section{OBJETIVOS DA PERSPECTIVA CLIENTES}

No âmbito da Gestão de Compras de uma UG, como um ente da administração pública, os clientes analisados são a sociedade brasileira, os fornecedores e os servidores requisitantes dos bens e serviços. Sobre isto, o questionário buscou, a partir de Echeveste (2005) e Günther (2003), obter uma pesquisa de percepção dos respondentes sobre a relação entre a Gestão de Compras e seus clientes.

Figura 4 - Percepção de relação dos clientes da UG sobre as Compras

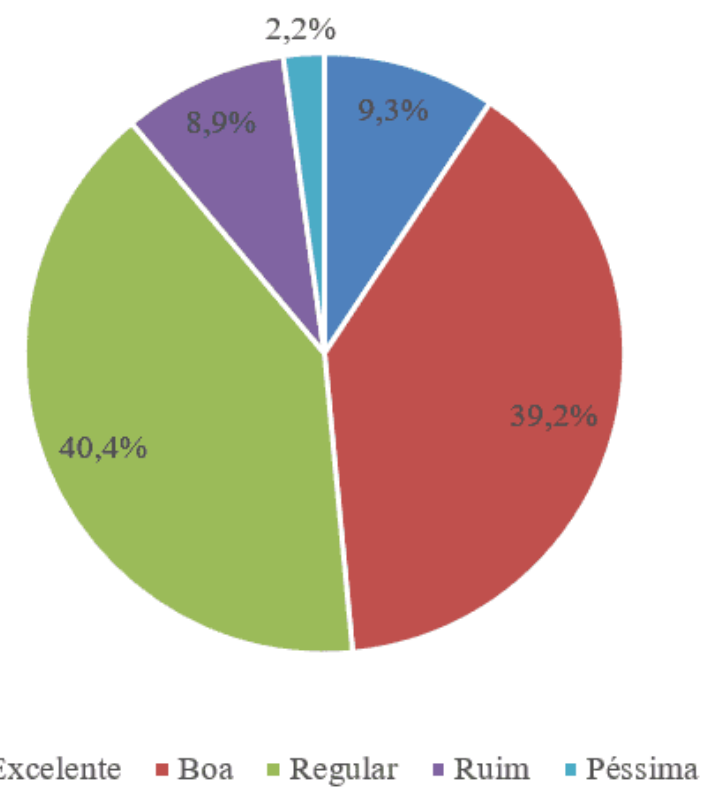

Fonte: Dados da pesquisa, 2020.

Observa-se que a maioria dos respondentes acredita que a relação é regular ou boa. Logo, depreende-se que os objetivos nesta perspectiva estão em um nível de percepção satisfatória (GÜNTHER, 2003). Sobre isto, Ghelman e Costa (2006) abordam que a relação da gestão de compras deve proporcionar a satisfação e 
integração da sociedade e dos servidores do EB, além de lidar com legalidade e equidade os fornecedores.

Nota-se que uma Organização Militar possui viés social de proporcionar segurança de ameaças internas e externas, além apoiar em diversas missões secundárias, como em Operações de Garantia da Lei e da Ordem, construção de pontes e rodovias, combate a secas, incêndios, doenças, entre outros (BRASIL, 2012). Nesse sentido, o cliente sociedade exige capacidade adequada para exercer esse papel através da aquisição efetiva e objetiva dos recursos necessários. No âmbito dos servidores do EB, observa-se que a SALC deve possuir uma relação de dedicação e capacitação desses indivíduos no intuito do aprimoramento e integração de todos envolvidos no sistema de compras. No que tange aos fornecedores, deve-se estabelecer uma relação impessoal com intuito de evitar o favorecimento ilegal de determinadas empresas.

\section{OBJETIVOS DA PERSPECTIVA PROCESSOS INTERNOS}

Essa perspectiva deve proporcionar, segundo Kaplan e Norton (2004), contínuo aprimoramento das práticas administrativas e da capacitação do capital humano, com a finalidade de alcançar eficiência na execução dos processos internos. No que tange aos processos internos da SALC, obteve-se através do questionário, propostas de otimização dos processos internos, abaixo descritas.

Quadro 5 - Respostas mais relevantes acerca dos processos internos

Citação direta dos questionados

"Um planejamento no início do ano que não sofra tantas alterações ao longo do mesmo."

"Uma maior integração dos setores envolvidos, o aprimoramento técnico individual dos integrantes, modernização do ambiente de trabalho assim como alguns sistemas como o SIAFI." 
"Dividir a SALC, pessoal e fisicamente, em seções distintas. Sendo uma seção como aquisições outra como licitações e por fim, uma responsável apenas por contratos."

"A principal coisa a ser feita é um bom planejamento da necessidade com antecedência."

"Conhecimento do processo de aquisição e objetividade no pedido de material e serviço."

"Aumento do efetivo da SALC."

“Maior definição e aplicação de metas e objetivos para cada integrante do Setor de Compras com vista ao trabalho de emprego dos recursos se torna mais eficiente e rápido."

Fonte: Dados da pesquisa, 2020.

Nesse sentido, através da análise de conteúdo dos resultados acima, percebe-se que a SALC necessita estabelecer objetivos que possibilitem o planejamento e a dinamização das práticas, além de estabelecer medidas internas de organização funcional interna do setor e maior integração entre todos os setores e, dependendo de cada caso das UG, buscar um aumento de efetivo que onerem o mínimo possível. Estes objetivos devem, conforme Serra, Torres e Torres (2004), tornar a gestão moderna, eficiente e organizada, no intuito de executar ações da forma correta, agir da forma mais adequada e realizar a escolha mais acertada.

\section{OBJETIVOS DA PERSPECTIVA APRENDIZADO E CRESCIMENTO}

Kaplan e Norton (1997) demostram a perspectiva de aprendizado e crescimento como o alicerce para atingir os objetivos das outras perspectivas, na medida em que, busca identificar as estruturas organizacionais necessárias para a geração de crescimento e aprimoramento. Sobre esse contexto, é necessário identificar as ações potenciais e capacitivas para que a SALC promova uma gestão de orçamento eficiente, processos internos que gerem valor aos clientes, além de integração e disseminação de conhecimentos, com a finalidade de otimizar a gestão de compras da UG. A partir 
disso, foi elaborado no questionário uma avaliação sobre as medidas mais relevantes para a execução desse contexto de aprendizado e crescimento:

Figura 5 - Propostas de ações de melhoria acerca de aprendizado e crescimento

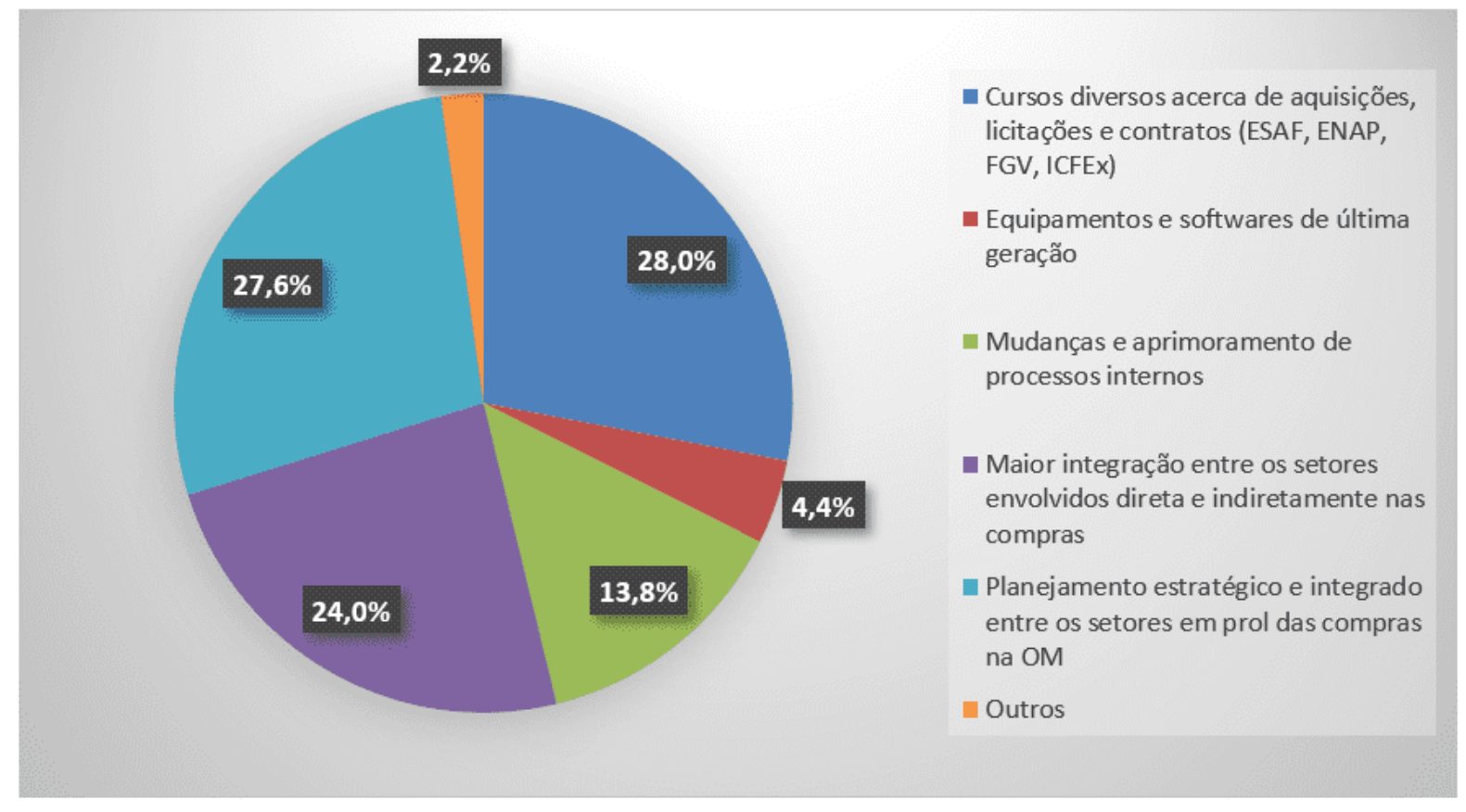

Fonte: Dados da pesquisa, 2020.

Através dos aspectos levantados em cada uma das quatro perspectivas do BSC, o Quadro 6 resume os objetivos elaborados para cada uma delas.

Quadro 6 - Objetivos das perspectivas do BSC para a SALC

\begin{tabular}{|c|c|c|}
\hline Perspectivas & Objetivos & \\
\hline Financeira & $\begin{array}{l}\text { Aumentar a eficiência dos } \\
\text { gastos }\end{array}$ & $\begin{array}{l}\text { Aumentar a arrecadação de } \\
\text { recursos para custeio }\end{array}$ \\
\hline Clientes & $\begin{array}{l}\text { Satisfação da sociedade e dos } \\
\text { servidores solicitante de bens e } \\
\text { serviços }\end{array}$ & $\begin{array}{l}\text { Tratamento legal, impessoal e } \\
\text { equitativo com os fornecedores }\end{array}$ \\
\hline $\begin{array}{l}\text { Processos } \\
\text { Internos }\end{array}$ & $\begin{array}{l}\text { Planejamento e otimização de } \\
\text { processos e ações internas }\end{array}$ & $\begin{array}{l}\text { Definir claramente organização } \\
\text { funcional interna }\end{array}$ \\
\hline
\end{tabular}




\begin{tabular}{|l|l|l|}
\hline & & $\begin{array}{l}\text { integralização com os setores } \\
\text { externos }\end{array}$ \\
\hline $\begin{array}{l}\text { Aprendizado e } \\
\text { Crescimento }\end{array}$ & $\begin{array}{l}\text { Desenvolvimento de ações de } \\
\text { atualização das atividades de } \\
\text { gestão de compras }\end{array}$ & $\begin{array}{l}\text { Criação de metodologias sobre } \\
\text { a importância do planejamento } \\
\text { em âmbito integrado }\end{array}$ \\
\hline
\end{tabular}

Fonte: Dados da pesquisa, 2020.

A formulação dos objetivos para as perspectivas do BSC tem como foco, conforme Kaplan e Norton (2004), que os objetivos estejam de acordo com a percepção dos indivíduos da organização. Isto possibilita elaborar um mapa estratégico para o setor que contemple as ações e metas necessárias e com poder de aceitação entre os integrantes da SALC.

\section{MAPA ESTRATÉGICO E RELAÇÕES DE CAUSA E EFEITO}

A última fase de aplicação do Balanced Scorecard consiste na elaboração do mapa estratégico, com a identificação das relações dos objetivos com cada perspectiva. Por conseguinte, é a representação gráfica do BSC que permitem visualizar os objetivos estrategicamente aplicados aos indicadores, metas e ações.

Quadro 7: Mapa estratégico da SALC

\begin{tabular}{|c|c|c|c|c|}
\hline Perspectiva & $\begin{array}{l}\text { Objetivos } \\
\text { Estratégicos }\end{array}$ & Indicadores & Metas & Ações \\
\hline Financeira & 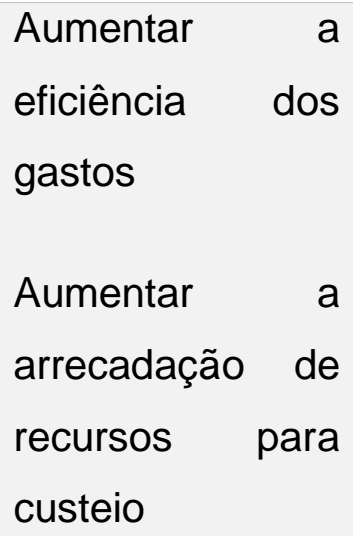 & $\begin{array}{l}\text { Recursos } \\
\text { orçamentários } \\
\text { empenhados e } \\
\text { liquidados no } \\
\text { SIAFI } \\
\text { Dados do } \\
\text { SIAFI de }\end{array}$ & $\begin{array}{ll}\text { Índice } & \text { de } \\
\text { emprego } & \text { de } \\
\text { recursos } & \\
\text { próximo a } & \\
100 \% & \end{array}$ & $\begin{array}{l}\text { Aumentar } \\
\text { número de } \\
\text { licitações e de } \\
\text { solicitações de } \\
\text { bens e serviços } \\
\text { Ampliar } \\
\text { contratos de }\end{array}$ \\
\hline
\end{tabular}


CONHECIMENTO https://www.nucleodoconhecimento.com.br

\begin{tabular}{|c|c|c|c|c|}
\hline & & $\begin{array}{l}\text { receitas } \\
\text { arrecadadas }\end{array}$ & $\begin{array}{l}\text { Obter } 20 \% \\
\text { de aumento } \\
\text { de receitas }\end{array}$ & $\begin{array}{l}\text { cessão de uso } \\
\text { na UG }\end{array}$ \\
\hline Clientes & $\begin{array}{l}\text { Satisfação da } \\
\text { sociedade e dos } \\
\text { servidores } \\
\text { solicitante de } \\
\text { bens e serviços. } \\
\text { Tratamento legal, } \\
\text { impessoal e } \\
\text { equitativo com os } \\
\text { fornecedores }\end{array}$ & $\begin{array}{l}\text { Número de } \\
\text { clientes } \\
\text { satisfeitos } \\
\text { Registro das } \\
\text { relações com } \\
\text { os } \\
\text { fornecedores }\end{array}$ & $\begin{array}{l}\text { Obter } \\
\text { avaliação } \\
\text { positiva } \\
\text { sobre o } \\
\text { desempenho } \\
\text { das compras } \\
\text { Evitar } \\
\text { dependência } \\
\text { de qualquer } \\
\text { fornecedor }\end{array}$ & $\begin{array}{l}\text { Pesquisa de } \\
\text { satisfação } \\
\text { Ter banco de } \\
\text { dados de } \\
\text { licitações } \\
\text { vigentes e de } \\
\text { fornecedores } \\
\text { com perfil } \\
\text { disponível para } \\
\text { realizar } \\
\text { compras }\end{array}$ \\
\hline $\begin{array}{l}\text { Processos } \\
\text { Internos }\end{array}$ & $\begin{array}{l}\text { Planejamento e } \\
\text { otimização de } \\
\text { processos e } \\
\text { ações internas } \\
\text { Definir } \\
\text { claramente a } \\
\text { organização } \\
\text { funcional interna } \\
\text { e integralização } \\
\text { com os setores } \\
\text { externos }\end{array}$ & $\begin{array}{l}\text { № de reuniões } \\
\text { de } \\
\text { planejamento e } \\
\text { avaliação de } \\
\text { desempenho } \\
\text { \% de } \\
\text { servidores que } \\
\text { aumentaram o } \\
\text { grau de } \\
\text { instrução sobre } \\
\text { seu papel na } \\
\text { gestão de } \\
\text { compras }\end{array}$ & $\begin{array}{l}\text { Reuniões } \\
\text { semanais } \\
\text { Aumentar } \\
\text { em } 20 \%\end{array}$ & 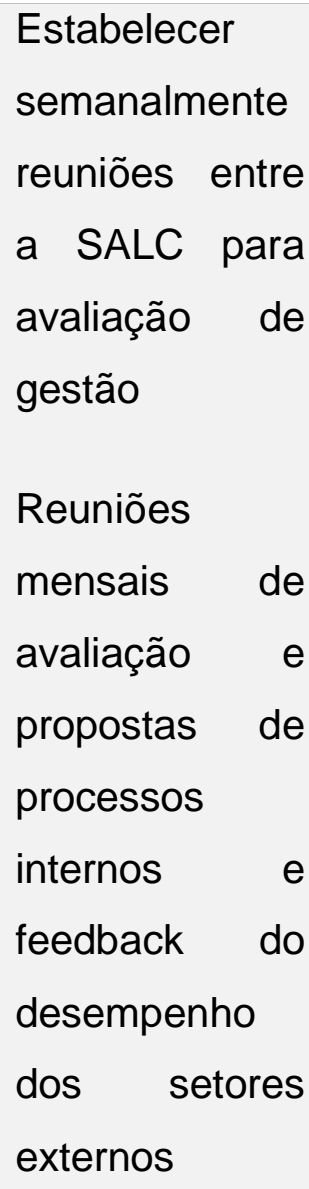 \\
\hline
\end{tabular}




\begin{tabular}{|c|c|c|c|c|}
\hline $\begin{array}{l}\text { Aprendizado } \\
\text { e } \\
\text { Crescimento }\end{array}$ & 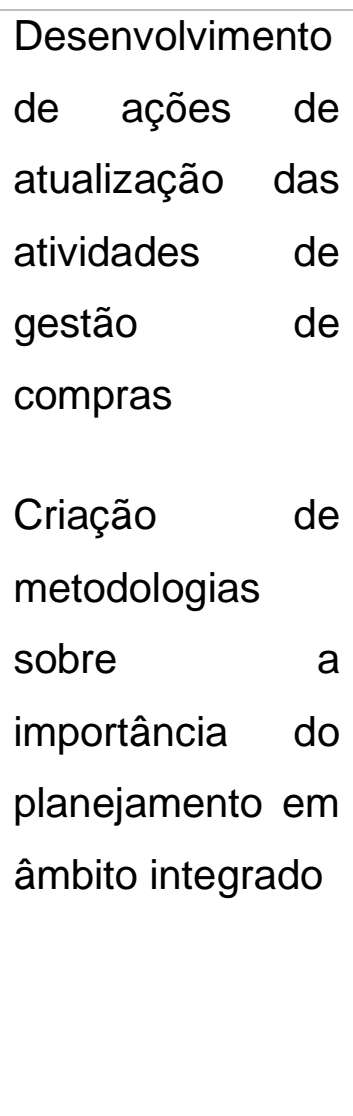 & $\begin{array}{l}\text { Número de } \\
\text { inscritos em } \\
\text { cursos de } \\
\text { aprimoramento } \\
\text { \% de iniciativas } \\
\text { mensais }\end{array}$ & $\begin{array}{l}\text { Aumento em } \\
20 \% \\
\text { Mínimo de } 4 \\
\text { iniciativas } \\
\text { mensais }\end{array}$ & $\begin{array}{l}\text { Disponibilizar } \\
\text { avisos de } \\
\text { cursos de } \\
\text { aprimoramento } \\
\text { e de novas } \\
\text { legislações e } \\
\text { manuais sobre } \\
\text { as compras } \\
\text { públicas } \\
\text { Criar uma } \\
\text { proposta } \\
\text { semanal de } \\
\text { interação } \\
\text { planejamento } \\
\text { de compras }\end{array}$ \\
\hline
\end{tabular}

Fonte: Dados da pesquisa, 2020.

Figura 6: Relações de causa e efeito da SALC

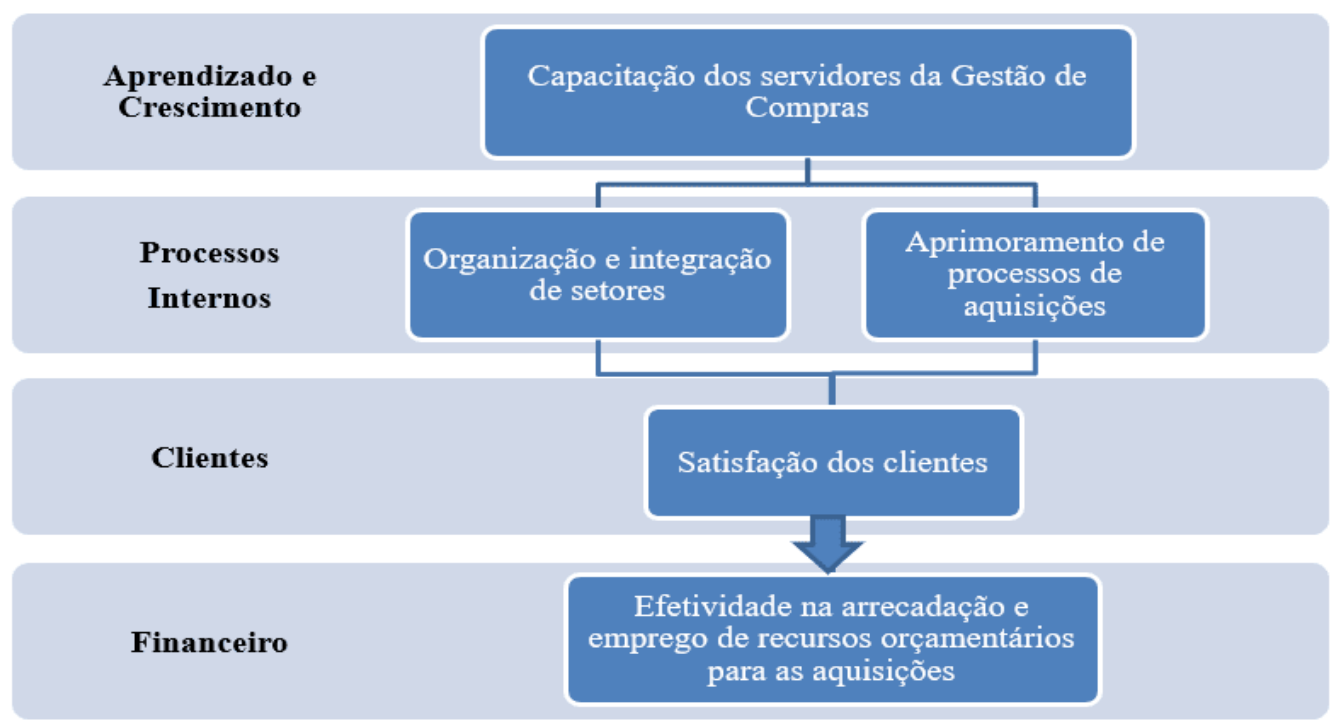

Fonte: Dados da pesquisa, 2020. 


\section{CONSIDERAÇÕES FINAIS}

O objetivo deste estudo foi analisar os impactos da metodologia Balanced Scorecard no setor de compras de Unidades Gestoras do Exército Brasileiro no Rio de Janeiro. Logo, colaborar com propostas que visam proporcionar progressos adequados a um processo efetivo de aquisições de bens e serviços.

O processo de aquisição de bens e serviços na Unidade Gestora, como ente da Administração Pública, é composto por estrutura de elementos legais e obrigatórios que cumpram os princípios que norteiam a atividade de compras. Quanto a isto, por meio do mapeamento do processo de Compra, foi identificado a organização verticalizada e burocrática em que a SALC está inserida. É um exemplo clássico, conforme Meirelles (2010), de uma organização pública brasileira pautada na legislação e regimentos específicos para cada atividade. Nesse sentido, a SALC deve buscar adequar e atualizar seus processos sobre esses preceitos, como também deve focar o processo de compras no princípio constitucional da eficiência para sanar as inconsistências observadas na aplicação do questionário acerca do emprego de recursos orçamentários.

Quanto ao ambiente interno, verificou-se que o pedido de material ou serviço é realizado pelo setor interessado, ao qual inicia o processo de compras. Todavia, através dos resultados obtidos nesta pesquisa, viu-se que por ser formulado por diferentes departamentos, o pedido de aquisição não é padronizado e apresenta erros na especificação de itens, que por seu turno, demanda tempo e resulta no retrabalho da SALC em adequar e corrigir esse documento. Portanto, pode-se indicar que a resolução deste problema reside na integração entre setores, com o fim de aprimorar a eficiência do sistema de compras.

Diante deste contexto, o setor de compras pode introduzir no processo de compras um planejado integrado que proporcione comunicação entre diversos setores, previsão e elaboração de cenários acerca da aplicação de recursos orçamentários, da disponibilidade de licitações e acompanhamento de estoques e pedidos. Conforme mencionado por Dias (2004) ao adotar um processo organizacional de fluidez e 
integração, como resultado ocorre o aprimoramento da qualidade da aquisição e entrega de suprimentos e serviços.

As análises obtidas pela pesquisa comprovam ainda que, embora a cultura do planejamento e integração não esteja plenamente incorporada a SALC, existe um cenário oportuno a criação de ações de fácil implantação para o setor, com a elaboração de estratégias, objetivos, metas e indicadores, como demonstrado no mapa estratégico.

A partir dos resultados, percebe-se também que a SALC ainda deve investir no processo de capacitação de seus indivíduos, em prol da atualização de novas práticas, leis, sistemas, métodos e tecnologias que auxiliem a atividade de compra e proporcionem mudanças e aprimoramento nos processos internos. Da mesma forma, deve desdobrar um processo de consciência e percepção da importância do planejamento estratégico integrado que atinja diretamente todos os setores, no que tange aos indivíduos e ao funcionamento e gestão dos departamentos que possuem papel secundário nas compras. Ou seja, é imprescindível adequar e atualizar a realidade administrativa e criar metodologias de trabalho que corroborem para o processo de planejamento e integração. A SALC deve ter como enfoque nessa perspectiva, desenvolver mecanismos que potencialize a capacidade e mitiguem as dificuldades encontradas no sistema de gestão de aquisição da Unidade Gestora.

Foi constatado também que, diante de inúmeras variáveis identificadas neste estudo, a aplicação do Balanced Scorecard no processo de gestão de compras tem a capacidade de oferecer uma visão sistêmica da organização, corroborando para a construção de objetivos adequados ao planejamento estratégico de compras de uma Unidade Gestora.

No entanto, cabe ressaltar que os objetivos deste estudo foram atingidos através do levantamento e análise dos dados, onde os resultados alcançados proporcionaram uma resolução adequada e consistente acerca do problema levantando. Desta maneira, este trabalho contribuiu no que diz respeito ao aprendizado sobre o tema, proporcionando adequado conhecimento dos impactos do BSC em um setor de 
compras da administração pública. Não obstante, o término dessa pesquisa não resulta obrigatoriamente no fim dessa discussão, podendo dessa forma ser aprofundada em estudos futuros, seja na análise e aplicação de outras práticas de melhorias, seja na reprodução em outras instituições do mesmo caráter.

\section{REFERÊNCIAS}

BALLOU, R. H. Gerenciamento da cadeia de suprimentos: planejamento, organização e logística empresarial. 5. ed. Porto Alegre: Boockman, 2006.

BOWERSOX, D. J.; CLOSS, D. J. Logística empresarial: o processo de integração da cadeia de suprimento. São Paulo. Atlas; 2004.

BRASIL. Constituição Federal de 1988. Promulgada em 5 de outubro de 1988. Disponível em: http://www.planalto.gov.br/ccivil_03/constituicao/constituição.htm.

BRASIL. Lei no 8.666, de 21 de junho de 1993. Regulamenta o art. 37, inciso XXI, da Constituição Federal, institui normas para licitações e contratos da Administração Pública e dá outras providências. Diário Oficial da União. Brasília, DF, 22 jun. 1993. Disponível em: https://www.planalto.gov.br/ccivil_03/leis/ I8666cons.htm. Acesso em: 24 jul. 2012

BRASIL. Portaria no 98.820, de 12 de janeiro de 1990: Aprova o Regulamento de Administração do Exército (RAE) - (R-3). Diário Oficial, Brasília, DF, 15 jan. 1990.

BRASIL. Tesouro Nacional (2016). Glossário. Disponível em: http://www3.tesouro.fazenda.gov.br/servicos/glossario/glossario_u.asp. Acesso em 7 de setembro de 2016.

CAMELO, M. B.; VIDAL, M. B. A Perspectiva de Aprendizado e Crescimento do Balanced Scorecard como Elemento Norteador das Ações de Endomarketing. São Paulo: XIII SIMPEP, 2006. 
CHIAVENATO, I. Planejamento estratégico: fundamentos e aplicações. Rio de Janeiro: Elsevier, 2003.

CREPALDI, S. A. Contabilidade Gerencial: Teoria e Prática. 3ª̣.ed. São Paulo: Atlas, 2004.

DALFOVO, O.; LIMA, M. P. Estudo para implantação do Balanced Scorecard em uma IES como um observatório da educação. Revista de Contabilidade do Mestrado em Ciências Contábeis da UERJ (online), v. 14, n. 3, p. 60-77, 2009.

DIAS, Marco Aurélio P. Administração de materiais: uma abordagem logística. São Paulo: Atlas, 2004.

DI PIETRO, M. S. Z. Direito administrativo. 24. ed. São Paulo: Atlas, 2011.

ECHEVESTE, M. E. Etapas de uma pesquisa de mercado e construção de questionário. UFRGS: Rio Grande do Sul, 2005.

GAITHER, N. \& FRAZIER, G. Administração da produção e operações. São Paulo: Pioneira Thomson Learning, 2001.

GHELMAN, S; COSTA, S. R. R. D. Adaptando o BSC para o setor público utilizando os conceitos de efetividade, eficácia e eficiência. São Paulo: XIII SIMPEP, 2006.

KAPLAN, R. S.; NORTON, D. P. A estratégia em ação: balanced scorecard. 14å . ed. Rio de Janeiro: Campus, 1997.

KAPLAN, R. S.; NORTON, D. P. Balanced Scorecard: indicadores que impulsionam o desempenho. Harvard Business Review: medindo o desempenho empresarial. Rio de Janeiro: Campus, 2000a.

KAPLAN, R. S.; NORTON, D. P. Organização Orientada para a Estratégia: como as empresas que adotaram o Balanced Scorecard prosperam no novo ambiente de negócios. Rio de Janeiro: Elsevier, 2001. 
KAPLAN, R. S.; NORTON, D. P. Mapas Estratégicos: Convertendo Ativos Intangíveis em resultados tangíveis. Rio de Janeiro: Elsevier, 2004

MARTINS, Petronio Garcia et ALT, Paulo Renato Campos (2001). Administração de Materias e Recursos Patrimoniais. São Paulo: Editora Saraiva.

MEIRELLES, H. L. Direito Administrativo Brasileiro. São Paulo: Malheiros, 2010.

MELGAÇO, M. M. Avaliando o desempenho de uma secretaria de governo. Banas Qualidade, São Paulo, 2003.

MOTA, F. G. L. Contabilidade Aplicada ao Setor Público. Brasília, DF, 2009.

MOTTA, R. Balanced scorecard em organizações públicas e sem fins lucrativos um sistema de medição para alinhar e gerenciar o sucesso da estratégia. Congresso Brasileiro da Qualidade e Produtividade, 13. Rio de Janeiro, 2003.

OSÓRIO, V. L. T. A utilização do Balanced Scorecard no aperfeiçoamento da administração pública gerencial: estudo de caso de uma autarquia municipal. 2003. 226f. Dissertação (Mestrado profissional em Gerência de Serviços) - Curso de Pós Graduação em Engenharia, Universidade Federal do Rio Grande do Sul, Porto Alegre, 2003.

PETRI, S. M.; ROSA, M. M.; BERNARDO, F. D.; BIANCO, P. Gestão pública através de mapas estratégicos do Balanced Scorecard: um estudo de caso do Festival Floripa Teatro Isnard Azevedo. Revista Catarinense da Ciência Contábil, v. 13, n. 40, p. 67-79, 2014.

PORTER, M. E. Estratégia Competitiva. Rio de Janeiro: Campus, 1986.

PORTER, M. E. Estratégia Competitiva: técnicas para análise de indústrias e da concorrência. 17. ed. Rio de Janeiro: Campus, 2004.

SANTOS, G. B. Aquisições e contratações dos bens e serviços comuns de interesse das Forças Armadas Brasileira: proposta de unificação. Trabalho de 
Conclusão de Curso ao Departamento de Estudos da Escola Superior de Guerra, Rio de Janeiro, 2011.

SERRA, F.;TORRES, M.C.S.;TORRES, A.P. Administração Estratégica: conceitos, roteiro prático e casos. Rio de Janeiro: Reichmann \& Affonso Editores, 2004.

VIEIRA, R. T.; PETRI, S. M. A contribuição do Balanced Scorecard na gestão estratégica de um escritório de contabilidade. Pensar Contábil, v. 16, n. 60, p. 4-13, 2014.

Enviado: Dezembro, 2020.

Aprovado: Dezembro, 2020. 